\title{
ALTERNATIVES FOR PRESERVATION OF BIOACTIVE COMPOUNDS IN BLUEBERRY PULP: HEAT TREATMENT ASSOCIATED WITH THE ADDITION OF XANTHAN PRUNI ${ }^{1}$
}

\author{
JÚLIA BORIN FIORAVANTE², VANESSA RODRIGUES DUARTE DE SOUZA, \\ ROSANE DA SILVA RODRIGUES ${ }^{4}$, PATRÍCIA DE OLIVEIRA DIAZ ${ }^{5}$, \\ ANGELITA DA SILVEIRA MOREIRA ${ }^{6}$
}

\begin{abstract}
In this study, to increase the preservation of phenolic bioactive compounds and antioxidant activity in blueberry pulp, heat treatment associated with addition of xanthan gum was used. A commercial mixture of blueberries (Powerblue, Climax and Bluegen cultivars) was added with $0.08 \%(\mathrm{w} / \mathrm{w})$ citric acid and subjected to heat treatment by direct heating until $90{ }^{\circ} \mathrm{C}$ in conventional open pan (OP) and by direct application of steam (AS); both with and without the addition of xanthan pruni (OPX and ASX), followed by pulping. Samples of only frozed fruits were considered as control. The five treatments remained under freezing and were evaluated until 90 days of storage for antioxidant activity, phenols, flavonoids and total monomeric anthocyanins. The results show that, with the exception of phenolics, heat treatment with direct steam application and xanthan addition favored bioactive compounds preservation during storage. These factors influenced positively on the anthocyanins stability during frozen storage for 90 days. The xanthan addition favored antioxidant activity preservation; preservation for antioxidant activity by ABTS and DPPH, in all heat treatments, was observed.
\end{abstract}

Index terms: Blueberry, Vaccinium ashei, fruit pulp, heat, fruit technology, storage.

\section{ALTERNATIVAS PARA PRESERVAÇÃO DE COMPOSTOS BIOATIVOS EM POLPAS DE MIRTILO: TRATAMENTO TÉRMICO ASSOCIADO À ADIÇÃO DE XANTANA PRUNI}

RESUMO- Neste estudo, objetivou-se aumentar a preservação de compostos bioativos fenólicos e atividade antioxidante em polpas de mirtilo, foi utilizado o tratamento térmico associado à adição de xantana pruni. Uma mistura comercial de mirtilos (cultivares Powerblue, Climax e Bluegen) foi adicionada com 0,08\% $(\mathrm{m} / \mathrm{m})$ e ácido cítrico e foi submetida a tratamento térmico por aquecimento direto até $90^{\circ} \mathrm{C}$ em tacho aberto convencional (OP) e por aplicação direta de vapor (ASX); com e sem a adição de xantana pruni (OPX e ASX). Amostras de frutas congeladas foram consideradas como controle. Os cinco tratamentos permaneceram sob congelamento e foram avaliados até 90 dias de armazenamento para atividade antioxidante, fenóis, flavonóides e antocianinas monoméricas totais. Os resultados mostram que, com exceção de fenólicos, o tratamento térmico com aplicação de vapor direto e adição de xantana pruni favoreceu a preservação dos compostos bioativos durante o armazenamento. Esses fatores influenciaram positivamente a estabilidade das antocianinas durante o armazenamento congelado por 90 dias. A adição de xantana nos tratamentos térmicos favoreceu a preservação da atividade antioxidante para os dois métodos (ABTS e DPPH).

Termos para indexação: Blueberry, Vaccinium ashei, polpa de fruta, calor, tecnologia de frutas armazenamento.

\footnotetext{
${ }_{1}^{1}$ (Paper 015-16). Received January 26, 2016. Accepted november 16, 2016.

${ }^{2}$ Post Graduate Program of Food Science and Technology, Federal University of Pelotas. E-mail: juliabfioravante@hotmail.com ${ }^{3}$ Post Graduate Program of Food Science and Technology, Federal University of Pelotas. E-mail: vanessatrak@yahoo.com.br ${ }^{4}$ Center for Chemical, Pharmaceutical and Food Sciences, Federal University of Pelotas. E-mail: fragatao@gmail.com ${ }^{5}$ Post graduate Program in Food Science and Technology, Post graduate Program in Biotechnology, Federal University of Pelotas. E-mail: bilicadiaz@yahoo.com.br

${ }^{6}$ Post graduate Program in Food Science and Technology, Post graduate Program in Biotechnology, Federal University of Pelotas. E-mail: angelitadasilveiramoreira@gmail.com
} 


\section{INTRODUCTION}

Blueberry (Vaccinium ashei Reade) is a fruit that has been highlighted by the concentration and composition of phenolic compounds (particularly anthocyanins) and, consequently, high antioxidant capacity. Some of the characteristics of the V. ashei species are: vigor, longevity, productivity, tolerance to heat and drought, problems with fungi and soil variations, low cold need, producing strong, firm and acid fruits. This species is very widespread in the southern region of Brazil (ANTUNES, 2006). Such activity has been associated with a reduction in the risk of developing numerous chronic noncommunicable diseases. In addition to the nutritional and functional appeal, its sensorial characteristics, especially color, have contributed to the growing interest in its cultivation. However, the perishability and seasonality of the fruit limit its commercialization and availability for the consumption in natura (RASEIRA; ANTUNES 2004).

Beneficiation of the fruit allows its availability in the off season, can add commercial value to the product and to possibility the use of fruit unappropriated for commercialization in natura, such as those very small size and uneven maturation. The most common processes are based on the application of thermal treatments that aim at the inactivation of enzymes responsible for nutritional losses, reduction of microbial load and stabilization of texture (BAHÇECI et al., 2005), besides increasing yield. Thus, preservation in pulp forms has been an alternative to meet the demand. In order to obtain pulps, it is ideal to carry out the mechanical pressing or pulping after the heat treatment because it avoids the degradation of compounds and oxidation by the polyphenoloxidases (TORALLES, VENDRUCOLO, 2007).

The heat treatment, however, can result in pulp with "baking taste", in case of overheating (TOLENTINO; GOMES, 2009). The use of the time/ temperature binomial is an important quality factor, not only in the nutritional, functional and sensorial aspects, but also in the microbiological safety of the pulp. Generally, better results are obtained when high temperatures are used for a short period of time (SOUZA, 2008). The use of new forms of heating application may provide reduction of bioactive compounds losses, improvement on extraction efficiency of these compounds, enzymes inactivation and microbiological control.

The heat treatments can be done in open pan, tubular pasteurizer or heat exchangers (RODRIGUES; SAINZ; FERRI 2009; KUCK 2012).
The use of direct steam allows adequate controll on the process temperature, important parameter to the preservation of thermolabile bioactive compounds, such as anthocyanins, which are sensitive to the intense temperature increase. Vigorous agitation by the bubbling of fruit mass caused by direct steam helps uniform temperature maintenance, avoiding points of overheating, detrimental to the process and that can impart strange flavors to the pulp (RIBEIRO, 2009).

The use of additives, such as citric acid and xanthan gum associated with thermal processes, has also been shown to have a positive influence on the preservation of bioactive compounds in some foods. Citric acid is widely used to adjust acidity, enhance flavor and activity of antioxidant compound and provide some degree of chemical stability to the product and exert preservative action. Many studies have indicated that the antimicrobial activity of citric acid is due to the chelation of metal ions essential for microbial growth (DAMODARAN; PARKIN; FENNEMA, 2010). In previous studies about blueberry products, desirable effects were observed with the addition of xanthan gum in preserving the color pulp (KUCK, 2012) and in toppings development (RODRIGUES; RODRIGUES; VENDRUSCOLO 2010). This is due to its encapsulating action on the compounds, reducing damages caused by heat, cold, variations in $\mathrm{pH}$, water activity, among others (SUTHERLAND, 1993). In addition, xanthan gum has important technological role in the elaboration of pulps and juices/nectars, due to its rheological properties that allow the formation of viscous solutions at low concentrations $(0,05-1,0 \%)$ and their high solubility in both hot and cold water (GARCÍA-OCHOA et al., 2000).

The objective of this work was to study alternatives for the preservation of bioactive compounds and antioxidant activity in blueberry pulp by thermal treatment (open pan heating and direct steam injection) associated with xanthan pruni addition

\section{MATERIAL AND METHODS}

A commercial blend of Blueberries (Vaccinium ashei Reade) Powerblue, Clímax e Bluegen, from Morro Redondo - RS (latitude $31^{\circ}$

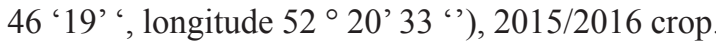
Rio Grande do Sul, Brasil was used. The fresh fruits were transported in a plastic box with a capacity of 46 liters. After selection of green fruits, leaves and other inappropriate fragments, the ripe fruits were 
sanitized in sodium hypochlorite solution at 100 $\mu \mathrm{L} . \mathrm{L}^{-1}$ for 10 minutes, followed by rinsing, draining and packing in low density polyethylene bags $(6 \mu)$, with approximately $2 \mathrm{~kg}$ of fruits per package, which were heat-sealed and kept under freezing $\left(-20^{\circ} \mathrm{C} \pm\right.$ $2^{\circ}$ ) for approximately 30 days, until the processing of the pulp.

The xanthan pruni was obtained by aerobic sucrose fermentation using Xanthomonas arboricola pv pruni strain 101, provided by the CPACT - Embrapa Temperate Climate Agricultural Research Center. The fermentation was carried out at the Laboratório de Biopolimeros of Centro de Desenvolvimento Tecnológico, Universidade Federal de Pelotas CDTec - UFPel, Brazil. Operating conditions were used as described in $\mathrm{WO} / 2006047845$ (VENDRUSCULO, 2006) and culture medium was in accordance to UNIVERSIDADE FEDERAL DE PELOOPS, (2015), with $\mathrm{pH}$ setted at 7 by addition of $2 \mathrm{M} \mathrm{NaOH}$, for $72 \mathrm{~h}$. The resulting fermented broth was thermally treated at $121^{\circ} \mathrm{C}$ for 15 minutes and the xanthan pruni was recovered by precipitation with addition of $96 \%$ ethanol in a ratio of $4: 1(\mathrm{v} / \mathrm{v})$. After recovery, the polymer was dried at $56^{\circ} \mathrm{C}$ until constant weight and milled to particle size of $60-150$ mesh. The final product was designated as xanthan pruni. All reagentes used were analitical grade.

The blueberry pulps were obtained in the food processing plant of the Instituto Federal Sul Riograndense - Campus Visconde da Graça, by direct heating of fruits conducted in an open pan (conventional method) and by heating with direct application of steam. The treatments studied were:

1) OP - open pan - heating in the open pan in wich the fruits were added with citric acid $(0,08 \%$ $\mathrm{w} / \mathrm{w})$ and $30 \%(\mathrm{w} / \mathrm{w})$ of water;

2) OPX - open pan with xanthan pruni heating in the open pan in wich the fruits were added with citric acid $(0,08 \% \mathrm{w} / \mathrm{w})$, xanthan pruni $(0,1 \%$ $\mathrm{w} / \mathrm{w})$ and $30 \%(\mathrm{w} / \mathrm{w})$ of water, condition selected in a preliminary study (KUCK, 2012);

3) AS - application of steam - heating by direct application of steam and addition of citric acid $(0,8 \% \mathrm{w} / \mathrm{w})$ and $30 \%(\mathrm{w} / \mathrm{w})$ of water;

4) ASX - application of steam - heating by direct application of steam and adition of citric acid $(0,08 \% \mathrm{w} / \mathrm{w})$, xanthan pruni $(0,1 \% \mathrm{w} / \mathrm{w})$ and $30 \%$ $(\mathrm{w} / \mathrm{w})$ of water.

5) Blueberry - Control - frozen blueberries without heating or addition of citric acid and xanthan.

To obtain the pulps by OP and OPX treatments, portions of $5 \mathrm{~kg}$ of fruits thawed at refrigerated temperature until $6 \pm 2{ }^{\circ} \mathrm{C}$ were used in each treatment. The fruits were heated until $70^{\circ}$
$\mathrm{C}$ and disintegrated with the aid of a stainless steel instrument to the point where the berry was detached from the bark. The fruits were then another time heated under stirring to $90^{\circ} \mathrm{C}$ in a stainless steel open pan with a rotating stem and a steam jacket generated in a thermal boiler with an outlet pressure of $2 \mathrm{~kg} . \mathrm{F}^{-1}$ and a temperature of $94^{\circ} \mathrm{C} \pm 5^{\circ}$. After this step, they were disintegrated in a single-stage horizontal mechanical pulper with $0.25 \mathrm{~mm}$ mesh for 3 minutes; the pulps were packed in polyethylene bags ( 6 microns) and stored under freezing $\left(-20^{\circ} \mathrm{C}\right.$ $\pm 2^{\circ}$ ) for 90 days.

To obtain pulps by AS and ASX treatments, portions of $5 \mathrm{~kg}$ of fruits thawed at room temperature until $6 \pm 2{ }^{\circ} \mathrm{C}$ were heated by direct application of steam generated in a thermal boiler (under the same exposed conditions above). The operation was carried out in $15 \mathrm{~L}$ stainless steel bucket, with a lid, with the fruit forming a layer of approximately $25 \mathrm{~cm}$. The steam insertion was performed by submerging a hose in the fruit mass. After about 5 minutes, when the fruits reached a temperature of $70^{\circ} \mathrm{C}$, they were crushed to berry and bark separation and returned to the bucket where the heat treatment was completed with steam injection up to $90^{\circ} \mathrm{C}$ for 5 minutes. After, they were pulped and stored, as described for pulps obtained by heating in open pan.

The determination of the bioactive compounds and the antioxidant activity were done in triplicate in the blueberry frozen for 30 days (considered 1st day of processing) and after 30,60 and 90 days of storage; and in the pulps of the four treatments (OP, OPX, AS, ASX) at the day of processing (day 1) and during storage at 30,60 and 90 days.

To determination of phenolic bioactive compounds (total phenolics, total flavonoids and monomeric anthocyanins) and antioxidant activity, extracts were prepared from samples of frozen blueberries and pulps of each treatment along the storage, according to Giusti and Worlstad (2001). Acidified methanol (1 M HCl, pH 1.0) was used as extractive solution. One gram of sample was weighed into a $50 \mathrm{~mL}$ Falcon tube and diluted into $25 \mathrm{~mL}$ of extraction solution, mixed in vortex and centrifuged $(10,000 \mathrm{xg}, 15 \mathrm{~min})$. The pellet was resuspended in the extraction solution three consecutive times. The supernatants were mixed and concentrated on a rotary evaporator at $40^{\circ} \mathrm{C}$ for $5 \mathrm{~min}$ up to $5 \mathrm{~mL}$ and were rising with the extractive solution to $25 \mathrm{~mL}$. The extracts were stored in a freezer $\left(-20^{\circ} \mathrm{C}\right)$.

Through reactions of the samples with solutions of Folin-Ciocalteau and sodium carbonate, the total phenols were determined colorimetrically, according Roesler (2007); in $500 \mu \mathrm{L}$ of concentrated 
metanolic extract, $2,5 \mathrm{~mL}$ of aqueous solution of Folin-Ciocalteau reagent at $10 \%(\mathrm{v} / \mathrm{v})$ and $2,0 \mathrm{~mL}$ of sodium carbonate solution at $7,5 \%(\mathrm{~m} / \mathrm{v})$ were added. The absorbance readings were accomplished to 760 $\mathrm{nm}$, being used methanol acidified as the white of the sample. The total phenols were quantified by curve of external calibration and the results expressed as $\mathrm{mg}$ of gallic acid equivalent (GAE) per 100g of sample.

Total flavonoid content was determined colorimetrically, according to Zhishen et al. (1999), with absorbance reading in a spectrophotometer at $510 \mathrm{~nm}$, after $20 \mathrm{~min}$, through reactions of the samples with $\mathrm{NaNO}_{2}, \mathrm{AlCl}_{3}$ and $\mathrm{NaOH}$. The result expressed in $\mathrm{mg}$ of catechin equivalent per $100 \mathrm{~g}$ of sample.

To determine monomeric antocianins, the $\mathrm{pH}$-differential method was used, in accordance with Giusti e Worlstad (2003), with the sample divided into two aliquots to which buffer solutions at $\mathrm{pH}$ $1.0(0,025 \mathrm{M}$ potassium chloride $)$ and $\mathrm{pH} 4.5(0,4 \mathrm{M}$ sodium acetate) were separately added. The analysis was done in a spectrophotometer at 520 and $700 \mathrm{~nm}$ after $15 \mathrm{~min}$. The molecular weight of cyanidin-3glycoside whose value is $\left(26,900 \mathrm{M}^{-1} \cdot \mathrm{cm}^{-1}\right)$. The final anthocyanin concentration is expressed as $\mathrm{mg}$ cyanidin-3-glycoside in $100 \mathrm{~g}$ of sample.

The antioxidant activity the blend of frozen blueberries and the pulps of the four treatments was evaluated by the spectrophotometric methods of radical sequestration DPPH and ABTS. For the determination of the total antioxidant activity by the $\mathrm{DPPH} \cdot$ method, we used the methodology of BrandWilliams et al. (1995), adapted for volume. The reaction was carried out at $515 \mathrm{~nm}$ after 30 minutes of reaction, during which time the complete purple coloration in the reaction occurred. In the ABTS method, total antioxidant activity was determined by the ABTS •+ assay, the system was kept at rest for 12 hours at room temperature in the absence of light. Once the ABTS • + was formed, it was diluted with distilled water to an absorbance value of 0,700 $\pm 0,02$ at $734 \mathrm{~nm}$, according to the method described by Lee et al. (1992). The results of the antioxidant activity were expressed in equivalent values of m.eq. Trolox g-1 (RE et al., 1999).

Technological characterization was carried out in triplicate, in the blend of frozen blueberrys for 30 days and in the pulps in the 1, 30, 60 and 90 of frozen storage. Determining total acidity (016/IV) hydrogen ionic potential (pH) (017/IV), total soluble solids content (010/IV). Titratable total acidity (\% citric acid) was performed by alkalinization to $\mathrm{pH} 8.1$, $\mathrm{pH}$ measured at $20^{\circ} \mathrm{C}$ in potentiometer and the total soluble solids content by refractometry at $20^{\circ} \mathrm{C}$ in a manual refractometer $\left(0^{\circ}-38^{\circ}\right)$ (Instituto Adolfo Lutz, 2008).

Statistical analysis was performed by analysis of variance (ANOVA), followed by the Tukey test for comparison of significant means, at 5\% significance, in Statistica software version 7.0. Pearson's correlation was performed to determine the degree of correlation between the bioactive components and the antioxidant activity, at $5 \%$ of significance, using the already cited software.

\section{RESULTS E DISCUSSION}

From the results presented in Table 1, it was observed that, in relation to the total phenolic compounds, the pulps of the OP and ASX treatments did not differ $(p>0.05)$ from the frozen fruit (control), during the storage period. Meantime, all the treatments showed a decrease in the total phenolic compounds (around 3\%) in 30 days of storage, with the exception of the OPX treatment, which showed a decrease in the 60th day of storage.

Treatment in open pan without xanthan pruni (OP) was the most efficient in the extraction of the total phenolic compounds from the fruit. The application of heat by conduction, which promotes the elevation of temperature more slowly than the direct application of steam, probably facilitated the rupture of the cell wall of the fruit skin facilitating the migration and extraction of these compounds. In blueberry, the great majority of its pigments is concentrated at the skin and, therefore, when it is submitted to a thermal treatment before the pulping, migration from the skin pigments to the fruit core occur, reducing the loss of pigments in the residue (BRAMBILLA; MAFFI; RIZZOLO, 2011). However, its pulp contains a large percentage of mucilaginous material, which makes it difficult to process (FRAGA, 2009).

Rossi et al. (2003) performed bleaching prior to the elaboration of blueberry juice and this treatment proved to be extremely effective in reducing the activity of polyphenoloxidases and, consequently, in the maintenance of the anthocyanins and the juice color.

The treatments with xanthan pruni addition (OPX and ASX) had equivalent values for flavonoids, but smaller than the treatment with steam, without addition of xanthan (AS). All pulps remained practically stable during the storage period, similar to that observed for total flavonoids. No synergism was observed between the protective effects of direct steam addition and xanthan gum.

The addition of xanthan may prejudice the 
extraction of some compounds, since it reduces the concentration of free water required for the dissolution of the compounds to be extracted from the skin.

The concentration of xanthan at the levels used did not demonstrate efficiency in the preservation of total phenols during storage. The acidification of the medium, on the other hand, contributed to the extraction and preservation of these compounds, with citric acid being the most recommended due to its complementary characteristics of preservative and stabilizer during storage (MAIN; CLYNDESDALE; FRANCIS, 1978). Rocha (2009), in evaluation of bleached blueberry pulp treated by bleaching at 90 ${ }^{\circ} \mathrm{C}$ for 1 minute, found total phenolic compound

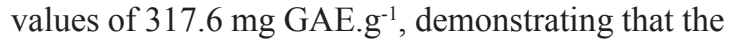
heat treatment used is closely linked to the content of bioactive compounds.

It is observed that the efficiency of the heat treatment can influence negatively or positively on the bioactive compounds. The correct application of the time/temperature binomial is an important factor that affects the quality, not only in the nutritional aspects, but also with respect to the sensorial quality and safety of the pulp (TOLENTINO; GOMES, 2009).

Table 1 shows that, in relation to total flavonoids content, the pulps of all treatments were significantly $(\mathrm{p} \leq 0,05)$ lower than the control (frozen blueberry), with losses between 35 and $60 \%$, on average, at the initial time. It can be observed that the applied thermal treatments exerted greater influence on the content of bioactive compounds than the storage time. AS and ASX treatments minimized the loss of flavonoids during processing and storage. At the end of 90 days, these treatments had the highest values of total flavonoids, evidencing that the heating by direct steam application prevented the degradation of these compounds.

As for the content of monomeric antocianins (Table 1), the results showed that, from the initial time (day 1) until the end of storage, all the treatments presented a significant reduction $(p \leq 0,05)$, in relation to the fruit that gave them origin, behavior also observed for total flavonoids (Table 1). The OP treatment had greater loss of anthocyanins in relation to the control (about 33\%), as well revealed lower values when compared to the other treatments, throughout the analyzed period.

The OPX, AS and ASX treatments didn't had significant difference among monomeric anthocyanins content at the initial storage time and these practically remained stable during the storage period. Kuck (2012) evaluated total anthocyanins by single $\mathrm{pH}$ method in blueberry pulps obtained by heat treatment in open pan and verifyed significant decrease from the 30th day of storage. In the present study, this was observed only for OP treatment.

Analyzing together flavonoids and anthocyanins values in relation to total phenolic compounds, was verified that OP treatment resulted in a higher extraction of total phenolic compounds, but not favored the extraction or preservation of total flavonoids and anthocyanins. The opposite was observed in the other treatments. This may be indicative that the association between heat treatment and the additives studied has an influence on the extraction (and preservation) of different classes of phenolic compounds, and that there are other classes of these compounds in a significant concentration that were not the subject of this study, such as condensed tannins (ROCHA et al., 2011).

It is verified in the Table 2 that all treatments resulted in pulps with antioxidant activities quite close to the values observed in the frozen blueberry. The use of thermal treatment prior to pulping and the consequent enzymatic inactivation favored the maintenance of the antioxidant activity of the pulps during storage, which were statistically different.

The antioxidant activity by DPPH radical remained more stable, with a maximum reduction of $16 \%$ at 90 days, when compared to the ABTS method, that resulted in a reduction of up to $67 \%$. The use of the heat treatment prior to the pulping of the blueberry is important, as it promotes the inactivation of the polyphenoloxidases and the increase of the permeability of the cells of the pericarp, where the pigments responsible for the antioxidant activity are stored. Heating by direct steam application was favorably significant only for activity tested by the ABTS method, throughout the storage period.

The content of total phenolic compounds showed a positive Pearson correlation $(\mathrm{p} \leq 0,10)$ with antioxidant activity by the two evaluation methods at the initial time $(r=0,065$ for ABTS and $r=0,001$ for DPPH). After 30 days of storage there was a positive correlation between phenolic compounds and antioxidant activity only by DPPH radical $(\mathrm{r}=$ 0,749 ).

At 60 and 90 days of storage no correlation was verified. However, in these periods, there was a positive correlation between antioxidant activity (by ABTS and DPPH) in relation to total monomeric anthocyanins $(r=0,001)$ and total flavonoids ( $\mathrm{r}=0,001)$. Silva, Vendruscolo and Toralles (2013), studying peach pulps (Prunus persica cv. Granada) stabilized by the addition of ascorbic acid and heat treatment, observed a correlation between 
the antioxidant capacity evaluation methods, DPPH and ABTS $(r=0,96513)$, which allowed to infer that there is proportionality between the two methods, being possible to opt for the use of only one of them. The differences found in the two methods are in the chemical nature of the two radicals. The ABTS radical is based on the generation of blue / green coloration and is applicable to hydrophilic and lipophilic antioxidant systems. DPPH uses a radical dissolved in organic media and is therefore applicable to hydrophobic systems (MOYER et al., 2002).

Reque et al. (2014), for elaboration of blueberry juice, did not use thermal processing, using only commercial juice centrifuge. The juice was stored under refrigeration for 10 days, being evaluated every two days. The authors reported values of antioxidant activity in the fruit in natura of $29,20 \mathrm{mM}$ TE / $\mathrm{g}$ by the ABTS method, and $33,23 \mathrm{mg} . \mathrm{g}^{-1}$ trolox; the juice losted about $40 \%$ of its antioxidant activity during storage, probably due to the action of polyphenoloxidases, responsible for the degradation of phenolic compounds. These results demonstrated that only the low storage temperature of blueberry juice is not effective to maintain its bioactive properties stable for longer than 6 days.

In the table 3 can be seen that, in all treatments, comparatively to the frozen blueberrys, the pulps had smaller total titratable acidity values, variable but similar $\mathrm{pH}$ values and, in general, higher total soluble solids contents than the fruits. It is important to emphasize that the heating by direct steam application resulted in smaller soluble solids content, probably due to the incorporation of water by condensation of the steam. The heating at open pan contributed for acidity and soluble solids content increasing, since this treatment makes possible the evaporation of the water, differently of the treatments with steam application.

According to KUCK (2012), the preliminary crushing of the blueberry fruit, after the initial heat treatment, previously the pulping, causes an increase in acidity and, consequently, a reduction of $\mathrm{pH}$, by the destruction of the plant tissue structure, which allows a faster release and equalization of the natural acidity of the fruit. The addition of xanthan pruni, which is a natural polyelectrolyte, also contributes to the increase of acidity and reduction of $\mathrm{pH}$. However, this was not observed in this study, probably due to the application of heat in the different treatments that promoted the degradation of acids and solids concentration, besides the small incorporation of water derived from the application of steam, reducing the values for the treatments.

TABLE 1 - Bioactive compounds in commercial blends of blueberries and blueberry pulps during frozen storage $\left(-20^{\circ} \mathrm{C}\right)$.

\begin{tabular}{lcccc}
\hline \multicolumn{5}{c}{ Storage time (days) } \\
\hline & \multicolumn{5}{c}{$\mathbf{0}$} & $\mathbf{6 0}$ & $\mathbf{9 0}$ \\
\hline Treatments & \multicolumn{5}{c}{ Total phenolic compounds (mg GAE.100g } \\
Blueberry (control)
\end{tabular}

Means $(\mathrm{n}=3) \pm$ standard deviation. Distinct lower case letters in the same line represent significant difference among the averages at the storage time, different upper case letters in the column indicate significant differences among treatments for Tukey test ( $\mathrm{p} \leq 0.05)$. Where OP: thermal treatment of pulp in open pan, with citric acid adition; OPX: thermal treatment of pulp in open pan, with citric acid and xanthan adition; AS: thermal treatment of the pulp with steam, with citric acid adition; ASX: thermal treatment of the pulp with steam, with citric acid and xanthan adition; blueberry frozen (control) for 30 days. 
TABLE 2 - Antioxidant activity by ABTS and DPPH (m.eq. Trolox $\mathrm{g}^{-1}$ ) in blueberry and blueberry pulps during frozen storage $\left(-20^{\circ} \mathrm{C}\right)$.

\begin{tabular}{|c|c|c|c|c|}
\hline & \multicolumn{4}{|c|}{ Storage time (days) } \\
\hline & $\mathbf{0}$ & 30 & 60 & 90 \\
\hline & \multicolumn{4}{|c|}{ ABTS } \\
\hline \multicolumn{5}{|l|}{ Treatments } \\
\hline Blueberry(controle) & $3,42 \pm 0,04^{\mathrm{aA}}$ & $3,12 \pm 0,01^{\mathrm{bB}}$ & $3,46 \pm 0,12^{\mathrm{aA}}$ & $3,08 \pm 0,11^{\mathrm{bA}}$ \\
\hline$\overline{\mathrm{OP}}$ & $2,36 \pm 0,02^{\mathrm{aB}}$ & $1,99 \pm 0,09^{\mathrm{bE}}$ & $2,00 \pm 0,03^{\mathrm{bD}}$ & $1,89 \pm 0,10^{\mathrm{bD}}$ \\
\hline$\overline{\mathrm{OPX}}$ & $2,10 \pm 0,00^{\mathrm{aB}}$ & $2,22 \pm 0,03^{\mathrm{aD}}$ & $2,25 \pm 0,03^{\mathrm{aC}}$ & $2,16 \pm 0,02^{\mathrm{bC}}$ \\
\hline$\overline{\mathrm{AS}}$ & $3,02 \pm 0,02^{\mathrm{aA}}$ & $2,84 \pm 0,07^{\mathrm{bC}}$ & $2,79 \pm 0,02^{\mathrm{bB}}$ & $2,73 \pm 0,08^{\mathrm{bB}}$ \\
\hline ASX & $3,03 \pm 0,44^{\mathrm{bB}}$ & $3,46 \pm 0,02^{\mathrm{aA}}$ & $3,35 \pm 0,04^{\mathrm{aA}}$ & $3,02 \pm 0,05^{\mathrm{aA}}$ \\
\hline & \multicolumn{4}{|c|}{ DPPH } \\
\hline Bleberry(controle) & $42,60 \pm 0,52^{\mathrm{aA}}$ & $43,33 \pm 0,60^{\mathrm{aA}}$ & $43,10 \pm 1,65^{\mathrm{aA}}$ & $41,03 \pm 0,95^{\mathrm{aA}}$ \\
\hline$\overline{\mathrm{OP}}$ & $43,60 \pm 0,49^{\mathrm{aA}}$ & $41,00 \pm 0,95^{\mathrm{aAB}}$ & $35,26 \pm 3,32^{\mathrm{bC}}$ & $35,56 \pm 0,35^{\mathrm{bB}}$ \\
\hline$\overline{\mathrm{OPX}}$ & $41,16 \pm 0,06^{\mathrm{aB}}$ & $40,66 \pm 2,11^{\mathrm{aAB}}$ & $40,16 \pm 0,12^{\mathrm{aAB}}$ & $39,16 \pm 1,18^{\mathrm{aA}}$ \\
\hline AS & $40,60 \pm 0,10^{\mathrm{aB}}$ & $37,03 \pm 2,84^{\mathrm{aB}}$ & $35,90 \pm 1,22^{\mathrm{abBC}}$ & $34,06 \pm 0,59^{\mathrm{bB}}$ \\
\hline ASX & $42,76 \pm 0,78^{\mathrm{aA}}$ & $42,10 \pm 1,01^{\mathrm{aA}}$ & $41,43 \pm 0,59^{\mathrm{abA}}$ & $39,33 \pm 1,53^{\mathrm{bA}}$ \\
\hline
\end{tabular}

Means $(n=3) \pm$ standard deviation. Distinct lower case letters in the same line represent significant difference among the averages at the storage time, different upper case letters in the column indicate significant differences among treatments for Tukey test ( $\mathrm{p} \leq 0.05$ ). Where OP: thermal treatment of pulp in open pan, with citric acid adition; OPX: thermal treatment of pulp in open pan, with citric acid and xanthan adition; AS: thermal treatment of the pulp with steam, with citric acid adition; ASX: thermal treatment of the pulp with steam, with citric acid and xanthan adition; blueberry frozen (control) for 30 days.

TABLE 3 - Total titratable acidity, $\mathrm{pH}$ and total soluble solids in blueberry and blueberry pulps during frozen storage $\left(-20^{\circ} \mathrm{C}\right)$.

\begin{tabular}{|c|c|c|c|c|}
\hline & \multicolumn{4}{|c|}{ Storage time (days) } \\
\hline & $\mathbf{0}$ & 30 & 60 & 90 \\
\hline & \multicolumn{4}{|c|}{ Total Titratable Acidity (\% citric acid) } \\
\hline \multicolumn{5}{|l|}{ Treatments } \\
\hline Blueberry (control) & $0,66 \pm 0,00$ & - & - & - \\
\hline OP & $0,52 \pm 0,00^{\mathrm{cB}}$ & $0,57 \pm 0,01^{\mathrm{bB}}$ & $0,58 \pm 0,00^{\mathrm{aA}}$ & $0,59 \pm 0,00^{\mathrm{aA}}$ \\
\hline OPX & $0,54 \pm 0,00^{\mathrm{cA}}$ & $0,55 \pm 0,00^{\mathrm{bA}}$ & $0,55 \pm 0,00^{\mathrm{bB}}$ & $0,56 \pm 0,00^{\mathrm{aB}}$ \\
\hline AS & $0,40 \pm 0,00^{\mathrm{bD}}$ & $0,40 \pm 0,00^{\mathrm{bD}}$ & $0,46 \pm 0,00^{\mathrm{aD}}$ & $0,46 \pm 0,01^{\mathrm{aD}}$ \\
\hline ASX & $0,48 \pm 0,00^{\mathrm{bC}}$ & $0,47 \pm 0,00^{\mathrm{cC}}$ & $0,47 \pm 0,00^{\mathrm{cC}}$ & $0,49 \pm 0,00^{\mathrm{aC}}$ \\
\hline & \multicolumn{4}{|c|}{ pH } \\
\hline Blueberry (control) & $3,55 \pm 0,01$ & - & - & - \\
\hline OP & $3,52 \pm 0,02^{\mathrm{abA}}$ & $3,43 \pm 0,02^{\mathrm{cB}}$ & $3,55 \pm 0,05^{\mathrm{aB}}$ & $3,45 \pm 0,01^{\mathrm{bcB}}$ \\
\hline OPX & $3,51 \pm 0,01^{\mathrm{cA}}$ & $3,65 \pm 0,01^{\mathrm{bA}}$ & $3,76 \pm 0,01^{\mathrm{aA}}$ & $3,75 \pm 0,02^{\mathrm{aA}}$ \\
\hline $\mathrm{AS}$ & $3,43 \pm 0,03^{\mathrm{cB}}$ & $3,66 \pm 0,01^{\mathrm{bA}}$ & $3,74 \pm 0,00^{\mathrm{aA}}$ & $3,74 \pm 0,01^{\mathrm{aA}}$ \\
\hline \multirow[t]{2}{*}{ ASX } & $3,22 \pm 0,01^{\mathrm{dC}}$ & $3,67 \pm 0,03^{\mathrm{aA}}$ & $3,32 \pm 0,01^{\mathrm{cC}}$ & $3,43 \pm 0,02^{\mathrm{bB}}$ \\
\hline & \multicolumn{4}{|c|}{ Total Soluble Solids $\left({ }^{\circ}\right.$ Brix $)$} \\
\hline Blueberry (control) & $13,5 \pm 0,02$ & - & - & - \\
\hline OP & $14,12 \pm 0,03^{\mathrm{bB}}$ & $14,00 \pm 0,00^{\mathrm{cB}}$ & $14,20 \pm 0,00^{\mathrm{aB}}$ & $14,10 \pm 0,00^{\mathrm{bB}}$ \\
\hline OPX & $15,65 \pm 0,01^{\mathrm{bA}}$ & $16,03 \pm 0,38^{\mathrm{aA}}$ & $16,01 \pm 0,08^{\mathrm{aA}}$ & $16,01 \pm 0,00^{\mathrm{aA}}$ \\
\hline $\mathrm{AS}$ & $11,00 \pm 0,00^{\mathrm{aD}}$ & $10,63 \pm 0,00^{\mathrm{abC}}$ & $10,11 \pm 0,00^{\mathrm{cC}}$ & $10,13 \pm 0,06^{\mathrm{bcC}}$ \\
\hline ASX & $13,77 \pm 0,07^{\mathrm{cC}}$ & $14,00 \pm 0,01^{\mathrm{bB}}$ & $14,10 \pm 0,00^{\mathrm{aB}}$ & $14,11 \pm 0,02^{\mathrm{aB}}$ \\
\hline
\end{tabular}

Means $(n=3) \pm$ standard deviation. Distinct lower case letters in the same line represent significant difference among the averages at the storage time, different upper case letters in the column indicate significant differences among treatments for Tukey test ( $\mathrm{p} \leq 0.05$ ). Where OP: thermal treatment of pulp in open pan, with citric acid adition; OPX: thermal treatment of pulp in open pan, with citric acid and xanthan adition; AS: thermal treatment of the pulp with steam, with citric acid adition; ASX: thermal treatment of the pulp with steam, with citric acid and xanthan adition; blueberry frozen (control) for 30 days. 


\section{CONCLUSION}

The direct steam application, associated to citric acid addition to the fruit (AS treatment), possibilits blueberry pulps production with highest total flavonoids and monomeric anthocyanins content. The xanthan pruni use, associated to citric acid addition and direct steam application (ASX treatment), enhance the stability of all studied compounds during pulp storage, resulting in the highest final phytochemics content and the highest antioxidant activities.

The direct steam application associated to xanthan addition has significant potential to development of blueberry pulps rich in bioactive compound and with high antioxidant activity.

\section{REFERENCES}

ANTUNES, L. E. C.; RASEIRA, M. C. B. Cultivo do mirtilo (Vacciniun spp.). Pelotas, Embrapa Clima Temperado, p.99, 2006.

BAHÇECI, K.S.; SERPEN, A.; GÖKMEN, V.; ACAR, J. Study lipoxygenase and peroxidase as indicator enzymes in Green beans: change of enzyme activity,ascorbic acid and clhorophylls during frozen storage. Journal of Food Engineering, Amsterdam, v.66, p. 187-192, 2005.

BRAMBILLA, A.; MAFFI, D.; RIZZOLO, A. Study of the influence of berry-blanching on syneresis in blueberry purées. Procedia Food Science, Amsterdam, v.1, p.1502-1508, 2011.

BRAND-WILLIAMS, W.; CUVELIER, M.E.; BERSER, C. Use of a free radical method to evaluate antioxidant. LWT - Food Science and Technology, Amsterdam, v.28, p.25-30, 1995.

DAMODARAN, S., PARKIN, K.L.; FENNEMA, O.R. Food dhemistry of fennema. $4^{\text {th }}$ ed. Porto Alegre: Artmed, 2010. 900p.

FRAGA, C.G. Plant phenolics and human health: biochemistry, nutrition and pharmacology. New Jersey: Wiley \& Sons, 2009. 593p.

GARCÍA-OCHOA, F.; SANTOS, V.E.; CASAS, J.A.; GÓMEZ, E. Xanthan gum: Production, recovery, and properties. Biotechnology Advances, Chicago, v.18, p.549-579, 2000.
GIUSTI, M.M.; WROLSTAD, R.E. Acylated anthocyanins from edible sources and their applications in food systems. Biochemical Engineering Journal, Amsterdam, v.14, p.217225, 2003.

INSTITUTO ADOLFO LUTZ. Métodos físicoquímicos para análise de alimentos. 4.ed. São Paulo: Instituto Adolfo Lutz, 2008. 1020p.

KUCK, L.S. Desenvolvimento de polpa de mirtilo (Vaccinium ashei Reade) e preservação das suas antocianinas para elaboração em alimentos. 2012. 127f. Dissertação (Mestrado em Ciência e Tecnologia Agroindustrial) - Faculdade de Agronomia Eliseu Maciel, Universidade Federal de Pelotas, Pelotas,2012.

LEE, H.S.; HONG K. Review chromatographic: analysis of anthocyanins. Journal of Chromatographic, Amsterdam, v.624, p.221234,1992.

MOYER, R.A.; HUMMER, C.E.; FINN, B.; FREI, E.R.E. Anthocyanins, phenolics, and antioxidant capacity in diverse small fruits: Vaccinium, Rubus, and Ribes, Journal of Agriculture and Food Chemistry, Washington, v.50, p.519-525, 2002.

RASEIRA, M. C. B.; ANTUNES, L. E. C. A cultura do Mirtilo (Vaccinium sp.). Pelotas: Embrapa Clima Temperado, 2004. 67p. (Série Documentos, 121).

RE, R.; PELLEGRINI, N.; PROTEGGENTE, A.; PANNALA, A.; YANG, M.; RICE- EVANS, C. Antioxidant activity applying an improved ABTS radical cation decolorization assay. Free Radical Biology and Medicine, New York, v.26, n.9-10, p.1231-1237, 1999.

REQUE, P.M.; STEFFENS, R.S.; JABLONSKI, A.; FLÔRES, S.H.; RIOS, A.O.; JONG, E.V. Cold storage of blueberry (Vaccinium spp.) fruits and juice: Anthocyanin stability and antioxidant activity. Journal of Food Composition and Analysis, v.33 p.111-116. 2014.

REQUE, P. M. Frutos de mirtilo (vaccinium spp.) e produtos derivados: caracterização e estabilidade de suas propriedades bioativas. 2012. $120 \mathrm{f}$. Dissertação (Mestrado) - Faculdade de Ciência e Tecnologia de Alimentos, Universidade Federal do Rio Grande do Sul, Porto Alegre, 2012. 
RIBEIRO, M.L. Efeito do processamento térmico nas características físico-químicas, nutricionais, microbiológicas e na atividade enzimática de polpa de mamão Formosa (Carica papaya L.). 2009. 105 f. Dissertação (Mestrado em Ciências dos Alimentos) - Faculdade de Engenharia de Alimentos, Campinas, 2009.

ROCHA, F. I. G. Avaliação da cor e da atividade antioxidante da polpa e extrato de mirtilo (Vaccinium myrtillus) em pó. 2009. 105f. Tese de Doutorado. Universidade Federal de Viçosa. 2009.

ROCHA, F.I.G. Avaliação da cor e da atividade antioxidante da polpa extrato de mirtilo (Vaccinium myrtillus) em pó. 2009. 105f. Tese (Doutorado) - Universidade Federal de Viçosa, Viçosa, 2009.

ROCHA, M.S.;FIGUEIREDO, R.W.;ARAUJO, M.A. da M.; MOREIRA-ARAUJO, R.S.R. Caracterização físico-química e atividade antioxidante (in vitro) de frutos do cerrado Piauiense. Revista Brasileira de Fruticultura, Jaboticabal, v.35, n.4, p.933-941, 2013.

RODRIGUES, R. da S.; SAINZ, R.L.; FERRI, V.C. Tecnologia de Frutas e Hortaliças - tecnologia de polpas e sucos de frutas e hortaliças. Pelotas: Editora e Gráfica Universitária UFPel, 2009. 55p.

RODRIGUES, S.A.; RODRIGUES, A.A.; VENDRUSCOLO, C.T. Effect of acidulants and thickeners in physico-chemical and structural blueberry topping. Brazilian Journal of Food Technology, Campinas, v.39, p.50-63, 2010.

ROESLER, R.; MALTA, L.G.; CARRASCO, L.C.; HOLANDA, R.B.; SOUSA, C.A.S.; PASTORE, G.M. Atividade Antioxidante de frutas do cerrado. Ciência e Tecnologia de Alimentos, Campinas, v.27, n.1, p.53-60, 2007.

ROSSI, M.; GIUSSANI, E.; MORELLI, R.; SCALZO, R. L.; NANI, R. C.; TORREGGIANI, D. Effect of fruit blanching on phenolics and radical scavenging activity of highbush blueberry juice. Food Research International, v.36, p.999-1005, 2003.
SILVA, R.S.; VENDRUSCOLO, J.L.; TORALLES, R.P. Avaliação da capacidade antioxidante em frutas produzidas na região sul do RS. Current Agricultural Science and Technology, Pelotas, V. 17, p. 392-400, 2013.

SOUZA, D. Estudo das propriedades físicas de polpas e néctares de pequenos frutos. 2008. $191 \mathrm{f}$. Dissertação (Mestrado em Engenharia) - Escola de Engenharia, Universidade Federal do Rio Grande do Sul, Porto Alegre, 2008.

SUTHERLAND, I.W. Xanthan. In: SWINGS, J.G.; CIVEROLO, E.L. Xanthomonas. London: Chapman \& Hall, 1993. p.363-388.

TOLEnTINO, V.R.; GOMES, A. Processamento de vegetais: polpas e frutas congeladas. Nitéroi: Programa Rio Rural, 2009. 24p.

TORALLES, R. P.; VENDRUSCOLO, J. L. S. Processamento do purê e néctar de pêssego. Comunicado Técnico 159, Pelotas: Embrapa Clima Temperado, 2007.

VENDRUSCOLO, C. T. ; MOREIRA, A. S. ; VENDRUSCOLO, J. L. S. . Meio de cultura para crescimento de Xanthomonas. 2004, Brasil. Número do registro: BR1220140300158, título: "Meio de cultura para crescimento de Xanthomonas", Instituição de registro: INPI - Instituto Nacional da Propriedade Industrial, Depositante (s): Angelita da Silveira Moreira;João Luis Silva Vendruscolo;Claire Tondo Vendruscolo;Empresa Brasileira de Pesquisa Agropecuária;Universidade Federal de Pelotas (2004).

VENDRUSCOLO, C.T.; VENDRUSCULO, J.L.; MOREIRA, A.S. (Inventores). Process for preparing a xanthan biopolymer. Brasil. Pelotas: Universidade Federal De Pelotas, Empresa Brasileira de Pesquisa Agropecuária, Patent $n^{\circ}$ WO/2006/047845, 11 maio 2005.

ZHISHEN J.; MENGCHENG T.; JIANMING W. The determination of flavonoid contents in mulberry and their scavenging effects on superoxide radicals. Food Chemistry, London, v.64, p.555-559. 1999. 